\title{
Retrospective analysis of the application of the Braden Q scale in pediatric intensive care
}

\section{Análise retrospectiva da aplicação da escala de Braden Q em terapia intensiva pediátrica}

\section{Análisis retrospectivo de la aplicación de la escala de Braden Q en terapia intensiva pediátrica}

\author{
Marcelli Cristine Vocci 1,*, Amanda Sayuri Sitoo Onary', Meire Cristina Novelli e Castro ${ }^{1}$, \\ Amanda Fabíola de Oliveira Spadotto ${ }^{1}$, Cassiana Mendes Bertoncello Fontes ${ }^{1}$
}

\section{ORCID IDS}

Vocci MC (D) https://orcid.org/0000-0003-0029-139X

Onary ASS (iD) https://orcid.org/0000-0002-5667-494X

Castro MCN (D) https://orcid.org/0000-0002-0590-4127

Spadotto AFO (D) https://orcid.org/0000-0003-3707-185X

Fontes CMB (D) https://orcid.org/0000-0002-6579-8637

\section{HOW TO CITE}

Vocci MC; Onary ASS; Castro MCN; Spadotto AFO; Fontes CMB. Retrospective analysis of the application of the Braden $\mathrm{Q}$ scale in pediatric intensive care. ESTIMA, Braz. J. Enterostomal Ther., 2020, 18: e2820. https://doi.org/10.30886/estima.v18.941_IN

\begin{abstract}
Objective: to characterize the profile of patients who developed pressure injuries and to analyze the retrospective scores obtained in the application of the Braden Q Scale in pediatric intensive care. Method: retrospective cohort study with analysis of secondary data from 34 electronic medical records of patients admitted to pediatric intensive care. Results: from the analysis of the scores obtained with the application of the Braden Q Scale, six records of pressure injuries were identified; the average age was 8.1 years; $66.6 \%$ were male; average of 41 days of hospitalization; main diagnoses are related to diseases of the respiratory, cardiac and neurological systems; all used invasive mechanical ventilation support and had a fasting prescription and use of a nasogastric tube. Conclusion: the clinical profile is correlated with the male gender, the higher frequency of respiratory diseases requiring mechanical ventilation, the use of vasoactive, vasopressor and sedative drugs, and the tube as a route of dietary administration. All of them had high risk scores for developing pressure injuries.
\end{abstract}

DESCRIPTORS: Pressure injury; Pediatric intensive care units; Critical care nursing; Stomatherapy.

\footnotetext{
1. Universidade Estadual Paulista Júlio de Mesquita Filho - Faculdade de Medicina de Botucatu - Departamento de Enfermagem Botucatu (SP), Brasil.

*Correspondence author: marcelli.vocci@unesp.br

Received: Aug. 24, 2020 | Accepted: Nov. 04, 2020
} 


\section{RESUMO}

Objetivo: caracterizar o perfil dos pacientes que desenvolveram lesão por pressão e analisar os escores retrospectivos obtidos na aplicação da Escala de Braden Q em terapia intensiva pediátrica. Método: estudo de coorte retrospectivo com análise de dados secundários de 34 prontuários eletrônicos de pacientes internados em terapia intensiva pediátrica. Resultados: da análise dos escores obtidos com aplicação da Escala de Braden Q, foram identificados seis registros de lesão por pressão; a média de idade foi de 8,1 anos; 66,6\% do sexo masculino; média de 41 dias de internação; principais diagnósticos estão relacionados a doenças do sistema respiratório, cardíaco e neurológico; todos utilizaram suporte de ventilação mecânica invasiva e apresentaram prescrição de jejum e uso de sonda nasogástrica. Conclusão: o perfil clínico está correlacionado ao sexo masculino, à maior frequência de doenças respiratórias com necessidade de ventilação mecânica, ao uso de drogas vasoativas, vasopressoras e sedativas, e à sonda como via de administração de dieta. Todos apresentaram escores de alto risco para desenvolvimento de lesão por pressão.

DESCRITORES: Lesão por pressão; Unidades de terapia intensiva pediátrica; Enfermagem de cuidados críticos; Estomaterapia.

\section{RESUMEN}

Objetivo: caracterizar el perfil de los pacientes que desarrollaron lesión por presión y analizar las puntuaciones retrospectivas obtenidas en la aplicación de la Escala de Braden Q en terapia intensiva pediátrica. Método: estudio de cohorte retrospectivo con análisis de datos secundarios de 34 historias clínicas electrónicas de pacientes internados en terapia intensiva pediátrica. Resultados: del análisis de las puntuaciones obtenidas con la aplicación de la Escala de Braden Q, se identificaron seis registros de lesión por presión; el promedio de edad fue de 8,1 años; 66,6 \% del sexo masculino; promedio de 41 días de internación; los principales diagnósticos se relacionan a enfermedades del sistema respiratorio, cardíaco y neurológico; todos utilizaron asistencia de ventilación mecánica invasiva y presentaron prescripción de ayuno y uso de sonda nasogástrica. Conclusión: el perfil clínico está correlacionado al sexo masculino, a la mayor frecuencia de enfermedades respiratorias que requieren ventilación mecánica, al uso de fármacos vasoactivos, vasopresores y sedantes y a la sonda como vía de administración de dieta. Todos presentaron puntuaciones de alto riesgo para el desarrollo de lesión por presión.

DESCRIPTORES: Lesión por presión; Unidades de terapia intensiva pediátrica; Enfermería de cuidados críticos; Estomaterapia.

\section{INTRODUCTION}

Institutionalization is usually an uncomfortable situation for the individual and their families, with peculiar aspects when it comes to child hospitalization, a fundamental phase in which the foundations of child development are established. It is, therefore, an unexpected event, in which the child goes through uncomfortable situations, such as adapting to institutional norms and rules, living with health professionals, in addition to performing painful exams and procedures ${ }^{1-3}$.

As an adverse event to institutionalization, pressure injury (PI) appears, which can delay recovery, prolong hospital stay, increase hospital costs and the workload of professionals, in addition to being associated with the mortality rate and being a traumatic event, whose injuries leave scars and a history on the child's body ${ }^{4,5}$.

Although the literature has a wide publication on the development of PI in adults, studies with pediatric patients are scarce, because the anatomical and pathophysiological conditions of child development, the prolonged hospital stay, the deficit of physical mobility, in addition to new technologies adapted to the context of intensive pediatrics put the pediatric patient at risk of developing $\mathrm{PI}^{6,7}$.

The susceptibility to the development of PI can be assessed by risk prediction instruments, which guide the use of preventive measures ${ }^{8}$. One of the best known and most used instruments in hospitals to help identify the risk of developing PI in pediatric patients is the Braden Q Scale (B-QS), developed in 2004, from the version for adult patients ${ }^{9}$, and adapted in 2011, cross-culturally, for use in Brazil ${ }^{10}$.

Currently, the prevention of $\mathrm{PI}$ is a challenging aspect for nurses and is based on the reduction or elimination of risks that may be subject to interventions, making it difficult to prevent and evaluate the effectiveness of any preventive measure without the knowledge and prediction of the risks of each patient. Thus, the development of PI is a multifactorial and extremely complex phenomenon, which can have a more effective prevention when the factors of greatest influence for its development are identified ${ }^{6}$.

Thus, the realization of this study on the importance of predictive instruments and the knowledge of the profile of pediatric patients at high risk or affected by 
PI may contribute to obtain relevant data on the little studied topic, since it will enable the dimensioning of the characteristics and the needs of this clientele, serving as a subsidy for the optimization of human and material resources in the prevention of injuries.

\section{OBJECTIVE}

To characterize the profile of patients who developed PI and to analyze the retrospective scores obtained in the application of B-QS in a pediatric intensive care unit (PICU).

\section{METHOD}

Retrospective cohort study carried out based on the analysis of secondary data obtained from the electronic medical record of patients admitted to the PICU of a public hospital.

The retrospective data collection period was from December 2015 to August 2018. The eligibility criteria were: complete registration and correct completion of at least three sequential Braden $\mathrm{Q}$ assessments. Thus, the total of 34 medical records were included.

\section{Braden Q scale}

Braden Q is composed of 7 subscales, which score scores from 1 to 4 . The final score varies between 7 and 28 points. The lower the value, the greater the commitment presented and, consequently, the greater the exposure to risk.

According to the scale criteria, the score is categorized into two general risk ranges, cut-off 22, with a high risk of developing PI when the final score is $<22$; and low risk of developing PI when the final score $\geq 22$.

The quantitative variables of the study were those that make up Braden Q: mobility, activity, perception, humidity, friction, nutrition, tissue perfusion and oxygenation.

\section{Data collection and analysis}

Data collection began in August 2018, after approval by the Research Ethics Committee (Comitê de Ética em Pesquisa - CAEE) 40752115.3.0000.5411, and ended in October 2018. The data were formally requested from the nucleus responsible for the maintenance and control of the Electronic Health Record System, and a list of patients admitted to pediatric intensive care from December 2015 to August 2018 was provided. From this list, the institution provided a computer with access to medical records for detailed analysis of the variables of interest.

The data were analyzed by a statistical professional, obtaining the descriptive statistics of the data, with frequency and percentages for qualitative variables; and mean, standard deviation, median, minimum and maximum for quantitative variables.

\section{RESULTS}

In the retrospective period chosen for data collection, 34 patients comprised the study sample. The general profile of the sample (Table 1) was characterized by the predominance of males 23 (67.65\%), mean of 4.40 years of age and the most frequent diagnoses were related to respiratory diseases 12 (35.29\%), cardiac 10 (29.41\%), neurological 6 (17.65\%) and neoplasic 6 (17.65\%).

Table 1. Characterization of the sample profile. Botucatu (SP), Brasil - 2019.

\begin{tabular}{|c|c|}
\hline Variables & $\mathrm{PICU}^{*}$ \\
\hline Age & n (\%) \\
\hline$<1$ year & $17(50.00)$ \\
\hline $1-5$ years & $4(11.76)$ \\
\hline $6-10$ years & 7 (20.59) \\
\hline $11-15$ years & $6(17.65)$ \\
\hline Total & $34(100.00)$ \\
\hline Gender & n (\%) \\
\hline Male & $23(67.65)$ \\
\hline Female & $11(32.35)$ \\
\hline Total & $34(100.00)$ \\
\hline Diagnostics & $\mathrm{n}(\%)$ \\
\hline Respiratory & $12(35.29)$ \\
\hline Cardiac & $10(29.41)$ \\
\hline Neurological & $6(17.65)$ \\
\hline Neoplasic & $6(17.65)$ \\
\hline Total & $34(100.00)$ \\
\hline
\end{tabular}

* PICU: pediatric intensive care unit 
The Braden Q application generated a total of 169 assessments during the retrospective study period. An average of 27 evaluations per patient was obtained, with a minimum of 13 and a maximum of 39 evaluations; the average of the total scores was 14 , showing that $34(100 \%)$ patients were at high risk of developing PI $(<22)$ in relation to the cutoff attributed by the scale.

The subscales of Braden Q that showed the lowest total percentage in the score, that is, the highest commitment were: activity, in $76 \%$ of the evaluations; mobility, by $50 \%$; friction and shear, by $32 \%$. The subscale that obtained the lowest average of the individual score of the 169 evaluations performed was the subscale "activity", with a mean of 1.3 (standard deviation \pm 0.96 ) of score. The best individual assessment, that is, the best average score between the assessments, was the subscale "humidity", with a mean of 2.8 (standard deviation \pm 0.88 )

Of the 34 records analyzed, in $6(17 \%)$ there was a record of PI development. The profile of these patients was characterized as (Table 2): average age of 8.1 years; 4 (66.67\%) were male; average of 41 days of hospitalization, minimum of 11 days and maximum of 65 days. All patients with a record of PI development were submitted to invasive mechanical ventilation and a delayed bladder probe; vasoactive and sedative drugs were used in $100 \%$ of those who developed PI; for the nutrition variable, 6 (100\%) patients had more than two fasting prescriptions at some point during the hospitalization period, with $4(66.67 \%)$ having a parenteral nutrition prescription and 2 (33.33), prescription of enteral diet via nasogastric tube.

Regarding the characterization and classification of the lesions identified in the medical records, the most affected place was the heel region, with 4 (66.7\%) injuries, and the sacral region, with 2 (33.3\%), being $3(50 \%)$ in stage 2 and 3 in stage $3(50 \%)$ of tissue impairment. The most used coverings were hydrocolloid, 3 (50\%) and papain, 3 (50\%).

The death record was identified in four of the six patients who developed PI.

\section{DISCUSSION}

The development of PI is related to the characteristics and clinical conditions of patients associated with the particularities of the care provided, thus revealing itself as a
Table 2. Characterization of the profile of patients who developed pressure injuries. Botucatu (SP), Brasil - 2019.

\begin{tabular}{|c|c|}
\hline Age & n (\%) \\
\hline$<1$ year & $3(50.00)$ \\
\hline $1-5$ years & $0(00.00)$ \\
\hline $6-10$ years & $2(33.33)$ \\
\hline 11 - 15 years & $1(16.67)$ \\
\hline Total & $6(100.00)$ \\
\hline Gender & n (\%) \\
\hline Male & $4(66.67)$ \\
\hline Female & $2(33.33)$ \\
\hline Total & $6(100.00)$ \\
\hline Diagnostics & n (\%) \\
\hline Respiratory & $2(33.33)$ \\
\hline Cardíac & $2(33.33)$ \\
\hline Neurological & $2(33.33)$ \\
\hline Total & $6(100.00)$ \\
\hline Hospitalization days & $\mathrm{n}(\%)$ \\
\hline $1-30$ days & $2(33.33)$ \\
\hline $31-65$ days & $4(66.67)$ \\
\hline Total & $6(100.00)$ \\
\hline Administration of the diet & $\mathrm{n}(\%)$ \\
\hline Enteral route & $2(33.33)$ \\
\hline Parenteral route & $4(66.67)$ \\
\hline Total & $6(100.00)$ \\
\hline
\end{tabular}

multifactorial problem. The clinical judgment of the nurse, based on scientific knowledge and practical experience, when combined with instruments that allow measuring the risk for the development of the injury in an objective way, can make the preventive process more effective ${ }^{11}$.

$\mathrm{B}-\mathrm{QS}$ proved to be an effective and reliable instrument with accuracy to predict the risk of developing PI in the pediatric population, reiterating the findings of other studies ${ }^{6,12}$, in which the patients who had the most critical scores during the evaluations, precisely, developed the condition. 
One of the risk factors for the development of PI is the institutionalization time, and the longer the patient stays under intensive care, the more likely they are to develop this condition ${ }^{13}$. The average number of days of hospitalization for patients who developed the disease was 41 , that is, greater than the other patients who were not affected (23 days).

In other studies ${ }^{14-15}$, the findings identified in relation to the most frequent diagnoses corroborate the data related to respiratory diseases identified in this study. It is known that the morbidities of this type of cause of PICU hospitalization interfere negatively, impairing the supply of oxygen to the tissues, that is, facilitating the development of PI.

Some medications used during hospitalization, especially those of continuous use, can contribute to the development of PI, such as vasoactive and vasopressor drugs. Due to hemodynamic instability, these drug classes are necessarily prescribed, and may predispose the development of PI by interfering with peripheral blood flow and tissue perfusion ${ }^{16-17}$. Sedation and analgesia in intensive care collaborate in the treatment of the severely ill patient, improving respiratory distress and adaptation to invasive mechanical ventilation. However, sedation is associated with the patient's mobility deficit, prolonged time on mechanical ventilation and increased rates of PI incidence ${ }^{18-19}$.

A study ${ }^{19}$ pointed PI as the most reported adverse event, both in patients with deep and mild sedation, showing that $20 \%$ of PI cases were related to sensory deficit caused by sedoanalgesic medications. Thus, the nurse must be able to identify this group, implementing targeted actions that can reduce the incidence of this condition and other complications.

Serious patients are usually using ventilatory support, therefore being an important risk factor due to the difficulty in maintaining their perfusion and adequate oxygenation for a longer time, in addition, ventilatory support often hinders the change of position and mobilization of the patient due to his hemodynamic instability, favoring the development of the lesion ${ }^{20-21}$.

Nutritional status has great importance on the body's physiological responses. During the analysis of data on the conditions of the patients who developed the condition, it was observed that the most used form of diet administration was via a nasogastric tube, and fasting was prescribed for all patients. In view of this, inadequate food consumption appears as one of the main causes and is directly related to the injury installation process. Situations that modify the way the patient eats, altering the digestive process, can compromise the physiological process of nutrient absorption and its adequate use for important physiological mechanisms of the organism ${ }^{22-23}$.

Among the subscales, "activity" obtained the lowest and highest individual score and was the one that most influenced the development of PI; the subscale "humidity" was the one that least influenced the development of PI. It is known that patients bedridden and/or with reduced activity are subject to the pressure factor, which plays a key role in the development of the condition ${ }^{14}$. In this study, the lack of activity (activity subscale) was one of the main risk factors for the development of the disease, this is due to the individual's inability to move, alternating positions in the bed to provide pressure relief in vulnerable areas of the body.

The subscale that quantified the humidity factor as a contributory factor for the development of PI had a higher score, which characterizes the quality of care, that is, the nursing team focuses on care and internal protocol the frequency of diaper changes every two hours.

When the development of a lesion is identified, it is essential to classify it for the proper choice of coverage to be used ${ }^{24-25}$. In the present study, stages 2 and 3 of PI were identified more frequently and, as a result, the most used coverings were hydrocolloid and papain. Hydrocolloid can also be used as a preventive measure in regions with a higher risk of developing the condition, and the damage possibly caused by friction can be reduced by the use of this protective barrier. Papain coverage is indicated for stage 3 and 4 lesions and for lesions that have devitalized tissues, providing bactericidal action, chemical debridement, anti-inflammatory action and reduction of local edema ${ }^{24-25}$.

As a limitation, this study presents a restricted number of participants due to the fact that the approached unit has only seven active beds and low turnover, thus it is not possible, therefore, to generalize the data, making evident the need for studies that establish data regarding the knowledge of the PI phenomenon in critical pediatric patients, still little studied. 


\section{CONCLUSION}

The clinical profile was characterized by male individuals, with a higher frequency of respiratory diseases requiring mechanical ventilation; use of vasoactive, vasopressor and sedative drugs; and use of a nasogastric or nasoenteral tube as the main route of diet administration. All patients had high risk scores for developing PI. Thus, the present study described the risk profile of pediatric patients vulnerable to the development of the disease as a form of surveillance and alert to the need to raise awareness among institutions and health professionals about the importance of risk assessment and individualized health planning, enabling these measures to be targeted according to the risk of each patient, optimizing human and material resources.

\section{ACKNOWLEDGEMENT}

The authors would like to thank CNPq/PROPe/ UNESP for the PIBIC scholarship 2018/2019.

\section{CONTRIBUIÇÃO DOS AUTORES}

Conceptualization: Vocci MC, Fontes CMB; Methodology: Vocci MC, Fontes CMB; Investigação: Vocci MC, Onary ASS; Writing - First Version: Vocci $\mathrm{MC}$, Onary ASS, Fontes CMB; Funding Acquisition: Fontes CMB; Resources: Fontes CMB, Vocci MC, Onary ASS; Supervision: Fontes CMB.

\section{REFERENCES}

1. Costa TS, Morais AC. Child hospitalization: child living from graphical representations. Rev Enferm UFPE on line 2017; [cited 2020 jun 18];11(Supl1):358-67. Available at: https:// periodicos.ufpe.br/revistas/revistaenfermagem/article/ view/11916

2. Gomes GLL, Fernandes MGM, Nóbrega MML. Ansiedade da hospitalização em crianças: análise conceitual. Rev Bras Enferm 2016;69(5):940-5. https://doi.org/10.1590/00347167-2015-0116

3. Santos GS, Pieszak GM, Gomes GC, Biazus CB, Silva SO Contributions of better childhood for growth and child development in family perception. Rev Pesqui Cuid Fundam. 2019; [cited 2020 jun 18];11(1):67-73. Available at: http:// www.seer.unirio.br/index.php/cuidadofundamental/article/ viewFile/6465/pdf_1

4. Matozinhos FP, Velasquez-Melendez G, Tiensoli SD, Moreira AD, Gomes FSL. Factors associated with the incidence of pressure ulcer during hospital stay. Rev Esc Enferm USP 2017;51:e03223. https://doi.org/10.1590/s1980$220 \times 2016015803223$

5. Ferreira MKM, Gurgel SS, Lima FET, Cardoso MVLML, Silva VM. Instruments for the care of pressure injury in pediatrics and hebiatrics: an integrative review of the literature. Rev Latino-Am Enfermagem 2018;26:e3034. https://doi. org/10.1590/1518-8345.2289.3034

6. Vocci MC, Fontes CMB, Abbade LPF. Pressure injury in the pediatric population: cohort study using the Braden Q scale. Adv Skin Wound Care 2018;31(10):456-61. https://doi. org/10.1097/01.ASW.0000542529.94557.0a

7. Rodrigues $\mathrm{CBO}$, Prado TN, Nascimento LCN, Laignier MR, Primo CC, Bringuente MEO. Management tools in nursing care for children with pressure injury. Rev Bras Enferm 2020;73(suppl4):e20180999. https://doi.org/10.1590/00347167-2018-0999

8. VasconcelosJMB, Caliri MHL. Nursing actions before and after a protocol for preventing pressure injury in intensive care. Esc Anna Nery 2017; [cited 2020 oct 29];21(1):e20170001. Available at: https://www.scielo.br/pdf/ean/v21n1/14148145-ean-21-01-e20170001.pdf

9. Curley MAQ, Razmus IS, Roberts KE, Wypij D. Predicting pressure ulcer risk in pediatric patients: the Braden Q scale. Nurs Res 2003;52(1):22-33. https://doi. org/10.1097/00006199-200301000-00004

10. Maia ACAR, Pellegrino DMS, Blanes L, Dini GM, Ferreira LM. Portuguese translation and validation of the Braden Q scale for predicting pressure ulcer risk in pediatric patients. Rev Paul Pediatr 2011;29(3):406-14. https://doi.org/10.1590/ S0103-05822011000300016

11. Souza MFC, Zanei SSV, Whitaker IY. Risk of pressure injury in the ICU: transcultural adaptation and reliability of EVARUCI. Acta Paul Enferm 2018;31(2):201-8. https://doi. org/10.1590/1982-0194201800029

12. Vocci MC, Toso LAR, Fontes CMB. Application of the Braden $Q$ scale at a pediatric intensive care unit. Rev enferm UFPE on line. 2017; [cited 2020 may 8];11(1):165-72. Available at: https://periodicos.ufpe.br/revistas/revistaenfermagem/ article/view/11890/14356

13. Campanili TCGF, Santos VLCG, Strazzieri-Pulido KC, Thomaz PBM, Nogueira PC. Incidence of pressure ulcers in cardiopulmonary intensive care unit patients. Rev Esc Enferm USP 2015;49(Esp):7-14. https://doi.org/10.1590/ S0080-623420150000700002 
14. Curley MAQ, Hasbani NR, Quigley SM, Stellar JJ, Pasek TA, Shelley SS et al. Predicting pressure injury risk in pediatric patients: the Braden QD scale. J Pediatr 2018;192(2):189-95. https://doi.org/10.1016/j.jpeds.2017.09.045

15. Smith HA, Moore Z, Tan MH. Cohort study to determine the risk of pressure ulcers and developing a care bundle within a paediatric intensive care unit setting. Intensive Crit Care Nurs 2019;53:68-72. https://doi.org/10.1016/j. iccn.2019.04.008

16. Cox J, Roche S. Vasopressors and development of pressure ulcers in adult critical care patients. Am J Crit Care 2015;24(6):501-10. https://doi.org/10.4037/ajcc2015123

17. Tallo FS, Vendrame LS, Lopes RD, Lopes AC. Invasive mechanical ventilation in the emergency room: a review for clinicians. Rev Bras Clin Med 2013; [cited 2020 jun 22];11(1):48-54. Available at: http://files.bvs.br/ upload/S/1679-1010/2013/v11n1/a3395.pdf

18. Santos $L R C L$, Lino AlA. Risks of pressure injury: application of the Braden scale in intensive care. ESTIMA, Braz J Enterostomal Ther 2018;16:e0818. https://doi. org/10.30886/estima.v16.443_PT

19. Barbosa TP, Beccaria LM, Silva DC, Bastos AS. Association between sedation and adverse events in intensive care patients. Acta Paul Enferm 2018,31(2):194-200. https://doi. org/10.1590/1982-0194201800028

20. Loudet $\mathrm{Cl}$, Marchena MC, Maradeo MR, Fernández SL, Romero MV, Valenzuela GE et al. Reducing pressure ulcers in patients with prolonged acute mechanical ventilation: a quasi-experimental study. Rev Bras Ter Intensiva 2017; [cited
2020 jun 20];29(1):39-46. Available at: https://www.scielo.br/ pdf/rbti/v29n1/0103-507X-rbti-29-01-0039.pdf

21. Miske LJ, Stetzer M, Garcia M, Stellar JJ. Airways and injuries: protecting our pediatric patients from respiratory device-related pressure injuries. Crit Care Nurs Clin North Am 2017;29(2):187-204. https://doi.org/10.1016/j. cnc.2017.01.006

22. Ministério da Saúde (BR). Manual de terapia nutricional na atenção especializada hospitalar no âmbito do Sistema Único de Saúde - SUS. $1^{\text {a }}$ ed. Brasília (DF): Ministério da Saúde; 2016.

23.S imony RF, Chaud DMA, Abreu ES, Blascovi-Assis SM. Nutritional status of neurological patients with reduced mobility. J Hum Growth Dev. (Online) 2014; [cited 2020 jul 1];24(1):42-48. Available at: http://pepsic.bvsalud.org/pdf/ $\mathrm{rbcdh} / \mathrm{v} 24 \mathrm{n} 1 / 06 . \mathrm{pdf}$

24. Vocci MC, Abbade LPF, Fontes CMB. Protocolo preventivo: lesão por pressão em unidades pediátricas. Botucatu: Universidade Estadual Paulista "Júlio de Mesquita Filho", Faculdade de Medicina, 2016; [cited 2020 jul 1]; $1^{\text {a }}$ ed. Available at: http://www.hcfmb.unesp.br/wp-content/ uploads/2015/09/Protocolo.pdf

25. National pressure ulcer advisory panel (NPIAP). Pressure injury stages. [Internet]. 2016 [cited 2020 jul 1]. Available at: https://npiap.com/page/PressurelnjuryStages1.

Costa TS, Morais AC. Child hospitalization: child living from graphical representations. Rev Enferm UFPE on line 2017; [citado 2020 jun 18];11(Supl1):358-67. Available at: https:// periodicos.ufpe.br/revistas/revistaenfermagem/article/ view/11916 